International Journal of Poultry Science 9 (2): 167-170, 2010

ISSN 1682-8356

(C) Asian Network for Scientific Information, 2010

\title{
Flock-Level Seroprevalence Against Ornithobacterium rhinotracheale among Broilers in Uruguay
}

\author{
K. Suzuki ${ }^{1}$, M. Petruccelli ${ }^{1}$, G. Trenchi ${ }^{2}$, G. Giossa ${ }^{2}$, G. Rodríguez ${ }^{2}$ and H. Trenchi ${ }^{2}$ \\ 'Laboratorio de Diagnóstico de Enfermedades de las Aves y los Pilíferos, \\ Facultad de Ciencias Veterinarias, Universidad Nacional de La Plata, Argentina \\ ${ }^{2}$ Área de Patología y Producción Avícola, Facultad de Veterinaria, \\ Universidad de la República, Montevideo, Uruguay
}

\begin{abstract}
The objective of this study was to estimate the true prevalence of seropositive broiler flocks against Ornithobacterium rhinotracheale in Uruguay, South America. Seventeen farms of broiler chickens greater than 35 days of age were studied. The field investigation was conducted between October 2008 and April 2009. Individual-chicken sera and pooled sera (containing 10 individual-chicken sera each) were analyzed using a commercial ELISA for the detection of antibody against Ornithobacterium rhinotracheale in chicken serum. A total of 181 pooled samples from the study area representing 17 farms were examined. Fifty-four pools were classified as test positive, because they included at least one individual-chicken classified as positive. On the basis of deterministic approach, the estimates for the apparent prevalence and true prevalence at flock-level were $30 \%$ and $17 \%$, respectively. The true prevalence estimate with the Bayesian model (stochastic approach) was slightly lower and having wider confidence intervals [11\% $(95 \% \mathrm{Cl}: 0 \%-$ $32 \%)]$.
\end{abstract}

Key words: Bayesian inference, pooling, rogan-gladen estimator

\section{INTRODUCTION}

Respiratory diseases have usually been an important concern in poultry industry. Diverse pathogens have been recognized as causing respiratory diseases, acting either in a primary or secondary role. Ornithobacterium rhinotracheale, a lately reported pathogen, is a Gram-negative, pleomorphic, rod-shaped bacterium associated with respiratory disease, growth retardation, mortality and decreased egg production in poultry (Van Empel et al., 2008). Ornithobacterium rhinotracheale can cause highly infectious diseases in poultry, but the severity of clinical symptoms, duration of the disease and mortality has been described to be highly variable (Bisgaard et al., 2008). Ornithobacterium rhinotracheale can be a primary or secondary etiological agent depending on strain virulence, adverse environmental elements, immune condition of the flock, and presence of other contagious agents (Bisgaard et al., 2008; Van Empel et al., 2008). There are reports of Ornithobacterium rhinotracheale infections in Europe, Africa, Middle East, Asia, Far East and North America (Loock et al., 2005; De Wit et al., 2008; Farhoodi et al., 2008; Van Empel et al., 2008). In South America, serological evidence of the Ornithobacterium rhinotracheale infection in Brazil has been observed (Arns et al., 1998). To our knowledge, no report of the Ornithobacterium rhinotracheale infection in Uruguay has been publicized.
Diagnostic tests are routinely utilized for poultry-health prevalence studies and ideally, True Prevalence (TP) should be estimated from Apparent Prevalence (AP) by modifying with test Sensitivity (Se) and Specificity (Sp). Absence of knowledge of or disregard for test errors (i.e. false positives and negatives) can lead to unsuitable sample size calculations for studies, misclassification of diseased and non-diseased conditions and prejudiced estimates of measures of result in risk factor studies. All of these opposingly influence disease studies, control and eradication programmes and, accordingly, animal trade. In recent years, applications of Bayesian analytic methods (which are concerned with the results of altering our previous beliefs as a result of adopting new data) for poultry-health prevalence survey data have increased (Herrero et al., 2009; Origlia et al., 2009; Suzuki et al., 2009). The objective of this study was to estimate the true prevalence of seropositive broiler flocks against Ornithobacterium rhinotracheale in Uruguay using the Rogan-Gladen estimator in combination with Bayesian inference.

\section{MATERIALS AND METHODS}

Study area: Uruguay is located in the south-eastern part of South America bordering the South Atlantic Ocean, between Argentina in the west and Brazil in the northeast. Uruguay has a poultry population of 14 million, a poultry meat production of 45,000 tonnes per

Corresponding Author: K. Suzuki, Laboratorio de Diagnóstico de Enfermedades de las Aves y los Piliferos, Facultad de Ciencias Veterinarias, Universidad Nacional de La Plata, Argentina 
year and a poultry egg production of 43,600 tonnes per year (FAO, 2009). The south side of the country including the capital city Montevideo and Canelones Department had the concentration of chicken population (about $90 \%$ of the total), because of in-and-around the big market Montevideo (Ministerio de Ganadería Agricultura y Pesca, 2009).

Sample collection: Seventeen farms of broiler chickens greater than 35 days of age were studied. Each study flock was randomly selected at different farms recruited from the capital city Montevideo, Canelones or Lavalleja (east of Canelones) Departments. None of the chickens had been vaccinated against Ornithobacterium rhinotracheale prior to sampling. The required total sample size of 1537 from a chicken population of 14 million was sufficient to produce a $95 \%$ confidence interval $(95 \% \mathrm{Cl})$ with a desired precision of $\pm 2.5 \%$ when the estimated AP was $50 \%$ (Hintze, 2008). The sample size in each of the farms was proportionally allocated ( $1 \%$ each of the total number of chickens at study farms) by the accessible financial, human and material means. The field investigation was conducted between October 2008 and April 2009, consisted of data collection through questionnaire interviews for each farm recruited, in conjunction with blood sample collections for each chicken (questionnaire results were not dealt with hereinafter).

Laboratory examinations: Blood samples collected were used for diagnostic investigations. Individualchicken sera and pooled sera (containing 10 individualchicken sera each) were analyzed using a commercial ELISA for the detection of antibody against Ornithobacterium rhinotracheale in chicken serum (FlockChek@ Ornithobacterium rhinotracheale Antibody Test Kit, Dr Bommeli AG, a subsidiary of IDEXX Laboratories, Liebefeld-Bern, Switzerland). Positive and negative controls were included for each series of samples analysed. For testing the pooled samples, the negative controls were not diluted at $1: 10$, which influenced the determination of a pool cut-off value. Absorbance was read on an ELISA reader at $650 \mathrm{~nm}$. On the basis of the instruction manual of the ELISA kits, serum samples with sample to positive (S/P) ratios greater than 0.4 (titres greater than 844) were considered seropositive. For the flock-level validation, a pooled sample was classified as test positive if at least one individual serum sample included in the pool had S/P ratio greater than 0.4 .

Data analysis: Data were entered into a database using the Base in the OpenOffice.org software version 3.1.1 (Sun Microsystems, Santa Clara, CA, USA). Each S/P ratio of all the pooled samples was used in a Receiver Operating Characteristic (ROC) curve analysis to derive a flock-level test classification. Within this analysis, the optimal cut-off (S/P ratio) for a given pool to achieve maximum flock-level Se and Sp of the pool testing when compared to flock classification based on individualchicken testing (used here as the gold-standard) was identified. As a descriptive measure of the ROC curve analysis, the Area Under the Curve (AUC) (that is maximum at $100 \%$ when both $S e$ and $S p$ are $100 \%$ ), was calculated using the Epi package version 1.1.7, in the $\mathrm{R}$ software version 2.9.2 ( $\mathrm{R}$ Development Core Team, 2008; Carstensen et al., 2009). The TP at flocklevel was derived from the AP using the Rogan-Gladen estimator (Rogan and Gladen, 1978) and information about the Se and Sp:

$$
\mathrm{TP}=\frac{A P+S p-1}{S e+S p-1}
$$

For estimation of TP on the basis of deterministic approach (with 95\% Cl) above, Survey Toolbox software version 1.04 was used (Cameron, 1999).

A Bayesian model was used to derive posterior Bayesian estimates (denoted $\mathrm{TP}_{\mathrm{B}}, \mathrm{Se}_{\mathrm{B}}$ and $\mathrm{Sp}_{\mathrm{B}}$ ) from prior distributions and the data from the study farm. Consider estimation of the seroprevalence where $y$ chickens tested positive out of $n$ chickens randomly selected. If the flock size $(N)$ is much larger than $n$, then the sampling distribution of $y$ is approximately binomial:

$$
y \mid T P_{B}, S e_{B}, S p_{B} \sim \text { Binomial }\left[n, T P_{B}{ }^{*} S e_{B}+\left(1-T P_{B}\right)\left(1-S p_{B}\right)\right]
$$

The authors modelled uncertainty about the $S e_{B}$ and $S p_{B}$ of the diagnostic test using independent beta prior distributions (Vose, 2008):

$$
\begin{aligned}
& S e_{B} \sim \operatorname{Beta}(d+1, n-d+1) \\
& S p_{B} \sim \operatorname{Beta}(d+1, n-d+1)
\end{aligned}
$$

Where $d$ is the number of desired (positive or negative) outcomes and $n$ is the number of samples tested. The infection seroprevalence using a mixture distribution was modelled:

$$
\begin{aligned}
& \operatorname{TP}_{\mathrm{B}} \sim \operatorname{Beta}(\mathrm{d}+1, \mathrm{n}-\mathrm{d}+1) \text { with probability } \tau \\
& \mathrm{TP}_{\mathrm{B}}=0 \text { with probability } 1-\tau
\end{aligned}
$$

Where $d$ is the number of desired (positive or negative) outcomes, $n$ is the number of samples tested and $\tau$ is the probability that the flock is infected. With this mixture distribution, computation of the posterior probability that the flock is not infected is possible and this computation can be performed easily using WinBUGS software version 1.4.3 under binomial-sampling schemes (Lunn et al., 2000). A beta prior distribution can also be used for $\tau$ (Vose, 2008). Alternatively, $\tau$ can be set equal to an expert-elicited constant ( $\tau 0$ ). The Markov chain-Monte Carlo simulation was run for 110,000 iterations of which 
Ihe first 10,000 Ileralıons were discarded as 'burn-ın' On lhe basis of Ihis stochastic approach, lhe posterior means and $95 \% \mathrm{Cl}$ (also called Bayesian credible Inlerval") were recorded for lhe TP, estimales and for posterior estımales of the lest characlerıstıcs, $\mathrm{Se}_{\mathrm{a}}$ and $\mathrm{Sp}$

\section{RE SULTS}

The 1861 chickens sludied accounled for aboul $1 \%$ of Ihe sludy chicken populalion and $0.01 \%$ of the lolal chicken populatıon in Uruguay A lolal of 181 pooled samples (c onsısting of 10 individuatchicken sera each) from lhe study area represenlıng 17 farms were examined with Ihe EUSA All Individual-chicken samples In the pools were also examined wlh the same assay Fifly-four pools were classiried as lest posilive, because Ihey included al least one indwidual-chicken classified as posilive In Ihis study, no pools were considered as questionable based on the individuatchicken resulls Figure 1 shows lhe ROC curve of nock-level screening

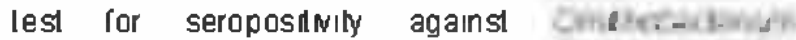
rhinolracheale A diagonal ROC curve (from lower lefi lo upper righl corner) indicales a diagnostic lest which does nol produce any useful differenlialion belween disease and non-diseased slales The ROC curve can be used lo adjust cul-off values according lo differenl diagnostic stralegies as follows If false-negalives and false-posilives are equally undesirable, a cut-of on the ROC curve should be selecled which is closest lo the upper lefl corner of the $Y$-Y charl Based on the ROC curve analysis, a pool cul-off value for SIP ralıo of 006 was delermined The AUC was $84 \%$ Al Ihis cul-of value, Ihe $\mathrm{Se}$ and $\mathrm{Sp}$ were estımaled $\mathrm{Io}$ be $80 \%$ and $80 \%$, respeclively (Table 1) The estimales for the AP and TP were $30 \%$ and $17 \%$, respeclively The posterior Bayesian estımales for the TP, $\mathrm{Se}_{\mathrm{a}}$ and $\mathrm{Sp}_{\mathrm{a}}$ were $11 \%$, $78 \%$ and $78 \%$, respeclively Table 1 shows the estımaled values for lest sensilivily, specificily and Irue seroprevalence against Ornilhobaclerum minolracheale al flock-level including 95\% $\mathrm{Cls}$, on the basıs of bolh delermınıstıc and slochastıc approaches

\section{DISCUSSION}

This study represents lhe first moderale-scale seroepıdemiological investigalion on Omitarulewus: rhindracheale in Uruguay an broller flocks The pool approach primany provided information on the seroprevalence of Ornihobaclerum rinndracheale al flock-level Informalion on individual-chicken seroprevalence had to be estımaled in a second step by assayıng all sera in the posilwe pools Depending on Ihe objeclwe of Ihis study, Ihis second step could be considered unneeded However, delerminıng flocks as posilve on pool lest resulls and the selecled pool c ul-off value would resull in false-posilive flock classific alions, and would nol provide Ihe informalion on Ihe wilhın flock seroprevalence The aulhors Iherefore recommend

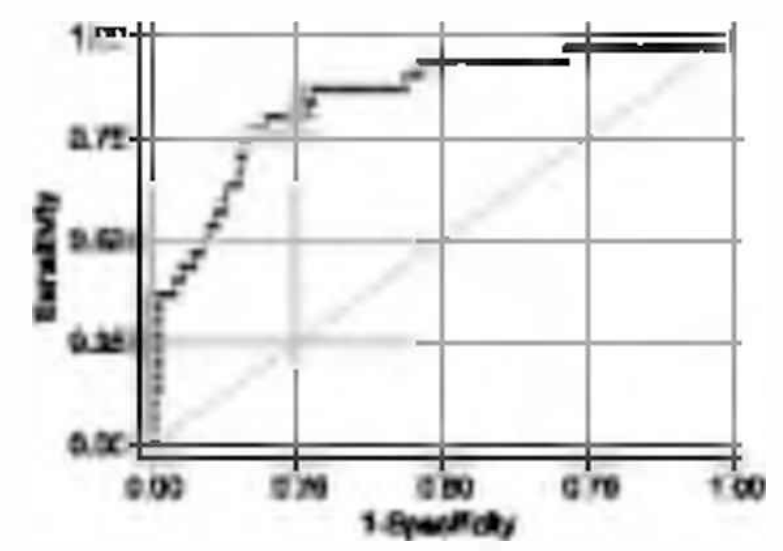

FIg 1 Oulpul Recener Operalıng Characlerıstıc (ROC) curve of nock-level screening lest for seroposilivily agaınst Ornihabaclerum rhindracheale among brollers in Uruguay ( $n=$ 181)

\begin{tabular}{|c|c|c|c|c|}
\hline Table 1 & \multicolumn{4}{|c|}{$\begin{array}{l}\text { Orndhohacbnum rhmodracheale among brollers in } \\
\text { Uruguay and to tesl characlerslics }(n=181)\end{array}$} \\
\hline & & 5th & & 9ક1h \\
\hline & & Percenble & Me an & Percenble \\
\hline \multicolumn{2}{|c|}{ App arem seroprevalence } & 0230 & 0298 & 0371 \\
\hline \multicolumn{5}{|c|}{ True seroprewdence } \\
\hline \multicolumn{2}{|c|}{ Delermıns lıc approach } & 0120 & $01 \mathrm{e6}$ & 0200 \\
\hline \multicolumn{2}{|c|}{ Stochas bc approach } & 0000 & 0112 & 0319 \\
\hline \multicolumn{5}{|c|}{ Sensilinly } \\
\hline \multicolumn{2}{|c|}{ Delermins lic approach } & 0014 & 0800 & 0920 \\
\hline \multicolumn{2}{|c|}{ Strchasbe approach } & 0013 & 0775 & 0901 \\
\hline \multicolumn{5}{|c|}{ Specifialy } \\
\hline \multicolumn{2}{|c|}{ Delermıns lıc approach } & 0729 & 0801 & 0862 \\
\hline \multicolumn{2}{|c|}{ Stochasbe a ooroach } & 0701 & 0779 & 0851 \\
\hline
\end{tabular}

Investigalıng individual-chicken samples from posilive pools whenever possible The AUC is a popular measure of the accuracy of a diagnostic lest olner Ihıngs being equal, Ihe larger Ihe $A \cup C$, Ihe beller lhe lest Is a predicled lhe existence of the disease The AUC values grealer Ihan $90 \%$ indic ale an exiremely weltrilıng model, values grealer Ihan 70\% indicale a moderalely welffiling model and values approaching 50\% Indicaling a model Ihal is no improvemenl on random allocalion of lest stalus (Hınlze, 2007) In Ihıs study, Ihe AUC was $84 \%$, which indic aled a moderalely weltfiling model The EUSA used in Ihis study salisfied the principal crileria (I e simpleness, speed, low cost, no specific equipment required and relalwely high sensilvily and high specificily when assayed at the flocklevel) needed for screenıng large numbers of samples in epidemiological studies II nonelheless remains significanl to modify lhe APs for the imperfecl lest characleristics The aulhors used both a Rogan-Gladen estımalor (delermınıstıc approach) and Bayesian Inference (slochastic approach) The approaches produced comparable TP estımales, wilh lhose of the 
Int. J. Poult. Sci., 9 (2): 167-170, 2010

Bayesian model being slightly lower and having wider confidence intervals. The Rogan-Gladen estimator has the advantage that it is more-widely recognized and also can be utilized as a simple deterministic purpose (entering fixed values for $\mathrm{AP}, \mathrm{Se}$ and $\mathrm{Sp}$ ). One disadvantage is that estimator (for certain combinations of $\mathrm{AP}, \mathrm{Se}$ and $\mathrm{Sp}$ ) can return negative results. The Bayesian stochastic approach is more complicated but relatively easily can be conducted in the freely available software WinBUGS. Its advantage is that, in addition to supplying posterior distributions for the $T P_{B}$, it also supplies posterior distributions (estimates) for $\mathrm{Se}_{\mathrm{B}}$ and $S p_{\mathrm{B}}$. However, knowledge and assumptions on the prior shape, value range and initializing values of the model inputs are needed.

\section{ACKNOWLEDGEMEMTS}

This study was carried out as part of the project for the capacity development for improvement of livestock hygiene in the southern part of South America through regional cooperation [commonly known as: Proyecto de desarrollo professional continuo para los veterinarios del Sur (PROVETSUR)], funded by the Japan International Cooperation Agency.

\section{REFERENCES}

Arns, C.W., H.M. Hafez, T. Yano, M.C.G.B. Monteiro, M. Celestino Alves, H.G. Domingues and L.T. Coswig, 1998. Ornithobacterium rhinotracheale: Detecção sorológica em aves matrizes e frangos de corte. In: Proceedings of Conferência Apinco 1998, São Paulo, pp: 55 (in Portuguese).

Bisgaard, M., A.M. Bojesen, J.P. Christensen, P. Mark, F.M. Paul, M.B. Janet and J.A. Dennis, 2008. Infections caused by species of Pasteurellaceae, Ornithobacterium and Riemerella: An introduction. Poultry Diseases, 6th Edn., W.B. Saunders, Edinburgh, pp: 146-148.

Cameron, A.R., 1999. Survey toolbox-a practical manual and software package for active surveillance of livestock diseases in developing countries. Australian Centre for International Agricultural Research, Canberra.

Carstensen, B., M. Plummer, E. Laara and M. Hills, 2009. Epi: A package for statistical analysis in epidemiology. R package version 1.1.7. Available from: http://CRAN.R-project.org/package=Epi.

De Wit, J.J., P. Mark, F.M. Paul, M.B. Janet and J.A. Dennis, 2008. Practical epidemiology of poultry disease and multifactorial conditions. Poultry Diseases, 6th Edn., W.B. Saunders, Edinburgh, pp: 492-509.
FAO, 2009. FAOSTAT. Rome. Available from: http://faostat.fao.org/.

Farhoodi, M., M. Kianizadeh, M. Banani, R. Toroghi, S.A. Pourbakhsh, H. Farzin and A. Sadrebazzaz, 2008. Application molecular methods on Escherichia coli and Ornithobacterium rhinotracheale infectious in commercial flocks of Southern Khorasan Province in Iran. Int. J. Infect. Dis., 12: e468-e469.

Herrero, M., K. Suzuki, J. Origlia, L. Nuñez, M. Faccioli, M. Silva, J. Caballero, O. Valiente and F. Álvarez, 2009. Probability mapping for Mycoplasma gallisepticum risk in backyard chickens in Paraguay. Int. J. Poult. Sci., 8: 565-569.

Hintze, J., 2007. NCSS 2007 software. NCSS, Kaysville, UT.

Hintze, J., 2008. PASS 2008 software. NCSS, Kaysville, UT.

Loock, M.V., T. Geens, L.D. Smit, H. Nauwynck, P.V. Empel, C. Naylor, H.M. Hafez, B.M. Goddeeris and D. Vanrompay, 2005. Key role of Chlamydophila psittaci on Belgian turkey farms in association with other respiratory pathogens. Vet. Microbiol., 107: 91101.

Lunn, D.J., A. Thomas, N. Best and D. Spiegelhalter, 2000. WinBUGS-a Bayesian modelling framework: concepts, structure and extensibility. Stat. Comput., 10: 325-337.

Ministerio de Ganadería Agricultura y Pesca, 2009. Division Contralor de Semovientes. Montevideo. Available from: http://muw.mgap.gub.uy/dgsg/ DICOSE/dicose.htm (in Spanish).

Origlia, J., K. Suzuki, L. Castro, M. Faccioli, M. Silva, J. Caballero, O. Valiente and F. Álvarez, 2009. Bayesian mapping for infectious bronchitis virus risk in backyard chickens in Paraguay. Int. J. Poult. Sci., 8: 740-745.

$\mathrm{R}$ Development Core Team, 2008. R: A language and environment for statistical computing. Available from: http://wnw. R-project.org.

Rogan, W.J. and B. Gladen, 1978. Estimating prevalence from results of a screening-test. Amer. J. Epidemiol., 107: 71-76.

Suzuki, K., J. Origlia, F. Álvarez, M. Faccioli, M. Silva, J. Caballero, L. Nuñez and L. Castro, 2009. Relative risk estimation for Mycoplasma synoviae in backyard chickens in Paraguay. Int. J. Poult. Sci., 8: 842-847.

Van Empel, P., P. Mark, F.M. Paul, M.B. Janet and J.A. Dennis, 2008. Ornithobacterium rhinotracheale. Poultry Diseases, 6th Edn., W.B. Saunders, Edinburgh, pp: 164-171.

Vose, D., 2008. Risk analysis: a quantitative guide, 3rd Edn., Wiley, Chichester, pp: 752. 